Authors' contribution/

Wkład autorów:

A. Zaplanowanie badań/

Study design

B. Zebranie danych/

Data collection

C. Analiza statystyczna/

Statistical analysis

D. Interpretacja danych/

Data interpretation

E. Przygotowanie tekstu/

Manuscript preparation

F. Opracowanie

piśmiennictwa/

Literature search

G. Pozyskanie funduszy/

Funds collection
ISSN 2083-3725

Volume 10, No. 4, 2017

\section{TOURISM AS A FACTOR OF REGIONAL DEVELOPMENT: THE CASE OF EASTERN SLOVAKIA*}

\section{TURYSTYKA JAKO CZYNNIK ROZWOJU REGIONALNEGO: STUDIUM PRZYPADKU SŁOWACJI WSCHODNIEJ}

\author{
Marian Gúčik ${ }^{(\mathrm{A}, \mathrm{B}, \mathrm{C}, \mathrm{D}, \mathrm{E}, \mathrm{F}, \mathrm{G})}$, Matúš Marcišs ${ }^{(\mathrm{A}, \mathrm{B}, \mathrm{C}, \mathrm{D}, \mathrm{E}, \mathrm{F}, \mathrm{G})}$
}

Matej Bel University in Banská Bystrica, The Faculty of Economics, Slovakia Uniwersytet Macieja Bela w Bańskiej Bystrzycy, Wydział Ekonomiczny, Słowacja

Gúčik M., Marciš M. (2017), Tourism as a factor of regional development: the case of eastern Slovakia/ Turystyka jako czynnik rozwoju regionalnego: studium przypadku Słowacji wschodniej. Economic and Regional Studies, Vol. 10, No. 4, pp. 86-95. https://doi.org/10.29316/ers-seir.2017.37

\section{Summary}

Subject and purpose of work: The subject of this study is the region of Eastern Slovakia. The aim of this paper is to evaluate the impact of tourism on regional development. To analyse the influence of tourism facilities on regional development selected indicators of tourism development are used.

Materials and methods: The material consists of data from the Statistical Office of the Slovak Republic, the Ministry of Transport and Construction of the Slovak Republic and selected municipalities. The data are processed by methods of descriptive statistics.

Results and conclusions: The article explains the importance of tourism in the development of the Eastern Slovakia region. Based on the analysis of economic impacts of tourism on the regional development we can conclude that tourism has minimal effects on this region.

Keywords: Slovakia, eastern Slovakia Region, regional development, tourism

\section{Streszczenie}

Przedmiot i cel pracy: Przedmiotem niniejszego opracowania jest region wschodniej Słowacji. Celem niniejszego artykułu jest ocena wpływu turystyki na rozwój regionalny. Do analizy wpływu obiektów turystycznych na rozwój regionalny wykorzystywane są wybrane wskaźniki rozwoju turystyki.

Materiały i metody: Materiał składa się z danych Urzędu Statystycznego Republiki Słowackiej, Ministerstwa Transportu i Budownictwa Republiki Słowackiej oraz wybranych gmin. Dane są przetwarzane za pomocą metod statystyki opisowej.

Wyniki i wnioski: Artykuł wyjaśnia znaczenie turystyki w rozwoju regionu wschodniej Słowacji. Na podstawie analizy gospodarczych wpływów turystyki na rozwój regionu Słowacji Wschodniej można wnioskować, że turystyka ma minimalny wpływ na ten region.

Słowa kluczowe: Słowacja, wschodnia Słowacja, rozwój regionalny, turystyka

Tabele: 6

Rysunki: 1

Literatura: 16

* The research has been completed within the research project VEGA: 1/0509/16 Perspectives of the Development of Voluntary Tourism in Slovakia/

Badania zostały zakończone w ramach projektu badawczego VEGA: 1/0509/16 Perspektywy Rozwoju Turystyki Dobrowolnej na Słowacji. 


\section{Introduction}

Tourism economic function has been emphasised as a stimulating factor for the economy and developing factor for the regions. Starting from 2013 the Slovakian government has recognised that the natural and historical potential in Slovakian regions is suitable for tourism development and it needs to be proactively supported through a targeted strategy. The Strategy of Development of Tourism until 2020 (2013) aims in particular to increase the competitive strength of tourism by better using its potential with the aim of alleviating regional disparities and creating new jobs. According to the possibilities and preconditions for tourism, in several regions it could be a key factor that could help the economic situation to improve. At the regional level, tourism responsibilities are delegated to eight self-governing regional governments: Bratislava, Trnava, Nitra, Trenčín, Žilina, Banská Bystrica, Prešov and Košice. Region of Prešov and Košice together creates a region of Eastern Slovakia, which is one of the four NUTS II regions. Municipalities likewise play an important role in the development of tourism in their areas. The region of Eastern Slovakia, which in terms of the country's potential (represented mainly by natural and historical attractions), has very good preconditions for tourism development.

\section{Theoretical backgrounds}

The region can be defined from different perspectives. The most appropriate definition depends on the purpose of the analysis. The basis for definition is its geographical explanation. Výrostová (2010) defined a region as a set of location units homogeneous with respect to their values on a particular set of characteristics. Most often, the region is defined from the administrative point of view for the purposes of state administration and territorial self-government. Gúčik et al. (2012) stressed that a tourism region cannot be identified with the administrative region because it belongs to a group of specific regions. In Slovakia, can be found 21 tourism regions. Each of them has different degree of attractiveness and importance (Tourism Regionalisation in Slovak Republic, 2005). In practise, these regions are not used for planning and accessing regional tourism development in Slovakia. Therefore, tourism regions defined from administrative approach have their reason in the form of an existing organizational structure, statistical data evaluation and planning regional development.

The regional development of tourism can activate general economic growth. However, some plans for development must be laid down in order to preserve resources and ensure complementarity between areas. Klamár (2016) characterizes the regional development as a process aimed at creating a viable and a productive region, building its competitiveness with the help of local potential and spatial diversity. Tourism development in the underdeveloped regions enables development of the periphery, retaining

\section{Wstęp}

Funkcja gospodarcza turystyki została wyróżniona jako czynnik stymulujący gospodarkę i czynnik rozwoju regionów. Począwszy od 2013 r. rząd słowacki uznaje, że naturalny i historyczny potencjał regionów słowackich nadaje się do rozwoju turystyki i musi być proaktywnie wspierany poprzez ukierunkowaną strategię. Strategia rozwoju turystyki do 2020 r. (2013 r.) ma na celu w szczególności zwiększenie siły konkurencyjnej turystyki poprzez lepsze wykorzystanie jej potencjału w celu złagodzenia regionalnych dysproporcji i tworzenia nowych miejsc pracy. Zgodnie z możliwościami i warunkami wstępnymi turystyki, w kilku regionach może to być kluczowy czynnik, który potencjalnie poprawi sytuację gospodarczą. Na poziomie regionalnym obowiązki w zakresie turystyki są powierzane ośmiu samorządom regionalnym: Bratysławy, Trnawy, Nitry, Trenczyna, Zyliny, Bańskiej Bystrzycy, Preszowa i Koszyc. Region Preszów i Koszyce wspólnie tworzą region wschodniej Słowacji, który jest jednym z czterech regionów NUTS II. Gminy również odgrywają ważną rolę w rozwoju turystyki na swoich obszarach. Region wschodniej Słowacji, który pod względem potencjału kraju (reprezentowanego głównie przez atrakcje przyrodnicze i historyczne) ma bardzo dobre warunki wstępne dla rozwoju turystyki.

\section{Podstawy teoretyczne}

Region można zdefiniować z różnych perspektyw. Najbardziej odpowiednia definicja zależy od celu analizy. Podstawą definicji jest jej wytłumaczenie geograficzne. Výrostová (2010) zdefiniowała region jako zbiór jednostek lokalizacji jednorodnych pod względem ich wartości na określonym zestawie cech. Najczęściej region jest określany z administracyjnego punktu widzenia dla celów administracji państwowej i samorządu terytorialnego. Gúčik i in. (2012) podkreślili, że regionu turystycznego nie można utożsamiać z regionem administracyjnym, ponieważ należy on do grupy określonych regionów. Na Słowacji znajduje się 21 regionów turystycznych. Każdy z nich ma inny stopień atrakcyjności i znaczenia (Regionalizacja Turystyki w Republice Słowackiej, 2005). W praktyce regiony te nie są wykorzystywane do planowania i dostępu do rozwoju turystyki regionalnej na Słowacji. Dlatego regiony turystyczne zdefiniowane w podejściu administracyjnym mają swój cel $\mathrm{w}$ postaci istniejącej struktury organizacyjnej, oceny danych statystycznych i planowania rozwoju regionalnego.

Regionalny rozwój turystyki może pobudzić ogólny wzrost gospodarczy. Należy jednak ustanowić pewne plany rozwoju, aby zachować zasoby i zapewnić komplementarność między obszarami. Klamár (2016) charakteryzuje rozwój regionalny jako proces mający na celu stworzenie realnego i produktywnego regionu, budowanie jego konkurencyjności za pomocą lokalnego potencjału i różnorodności przestrzennej. Rozwój turystyki w słabo rozwiniętych regionach umożliwia rozwój peryferii, zapobiega emi- 
the population in the homeland, infrastructure is improved as well as all other activities which contribute to the prosperity of the region and a country (Petrevska, Manasieva-Gerasimova, 2012).

The impacts of tourism can be economic, environmental, social and cultural. Each category includes positive and negative impacts (Hlavňová, Pavol, Sabo, 2014). Tourism could be a competitive advantage of region (Andraz, Norte, Goncalves, 2015). The character of economic impacts of tourism depends, in particular, on the policy of regional government (Table 1 ). gracji, poprawia się infrastruktura, a także wszelkie inne działania przyczyniające się do dobrobytu regionu i kraju (Petrevska, Manasieva-Gerasimova, 2012).

Skutki turystyki mogą mieć charakter gospodarczy, środowiskowy, społeczny i kulturowy. Każda kategoria zawiera pozytywne i negatywne skutki (Hlavňová, Pavol, Sabo, 2014). Turystyka może być przewagą konkurencyjną regionu (Andraz, Norte, Goncalves, 2015). Charakter gospodarczych wpływów turystyki zależy w szczególności od polityki rządu regionalnego (Tabela 1 ).

Table 1. The potential economic impacts of tourism on regional development

Tabela 1. Potencjalne skutki gospodarcze turystyki dla rozwoju regionalnego

\begin{tabular}{|l|l|}
\hline \multicolumn{1}{|c|}{ Positives of tourism } & Negatives of tourism \\
\hline - contributes to income and standard for living/ & - increases price of goods and services/ \\
przyczynia się do dochodów i standardu życia & podwyższa cenę towarów i usług \\
- improves local economy/ & collapse of the local industry/ \\
poprawia gospodarkę lokalną & upadek lokalnego przemysłu \\
- multiplier effect across different sectors/ & increases price of land and housing/ \\
efekt wzmocnienia w różnych sektorach & podwyższa cenę gruntów i mieszkań \\
- source of economic restructuring/ & property issue and sale of land/ \\
źródło restrukturyzacji gospodarczej & problem z nieruchomościami i sprzedaż gruntów \\
- improves regional competitiveness/ & - profits may be exported by non-local owners/ \\
poprawia konkurencyjność regionalną & zyski mogą być eksportowane przez zamiejscowych \\
- improves local budgets/ & właścicieli \\
poprawia budżety lokalne & - income inequality/ \\
- contributes to GDP/ & nierówności dochodów \\
przyczynia się do wzrostu PKB & - excessive construction of tourism establishments/ \\
- increases employment opportunities/ & nadmierna budowa obiektów turystycznych \\
zwiększa możliwości zatrudnienia & - increases potential for imported labour/ \\
- creates new business opportunities/ & zwiększa potencjał importowanej siły roboczej \\
tworzy nowe możliwości biznesowe & - cost for additional infrastructure/ \\
- creates prerequisite for cooperation/ & koszt dodatkowej infrastruktury \\
stwarza warunki do współpracy & - increases road maintenance/ \\
- increases opportunities for shopping/ & zwiększa usługi konserwacji dróg \\
zwiększa możliwości zakupów & - seasonal tourism and unemployment risk/ \\
- improves transport infrastructure/ & turystyka sezonowa i ryzyko bezrobocia \\
poprawia infrastrukturę transportową & -additional taxes/ \\
- increases tax revenues/ & dodatkowe podatki \\
zwiększa wpływy z podatków & \\
\hline
\end{tabular}

Source: Dwyer et al., 2004; Gúčik et al., 2012; Pedrana, 2013; Li et al., 2016; Dziuba, 2016.

Źródło: Dwyer i in., 2004; Gúčik i in., 2012; Pedrana, 2013; Li i in., 2016; Dziuba, 2016.

Not all impacts are applicable to every region because conditions or resources differ. While tourism can offer economic opportunities for regional development based on territorial resources, at the same time, tourism impacts on the utilization of these resources and the organization of economic systems can negatively contribute to the development and sustainability of a region as well.

\section{Aim, material and methodology}

The aim of this article is to examine the influence of tourism as a factor of development of the East Slovakia region. To analyse the importance of tourism in the region of East Slovakia, the selected indicators of tourism development are used. The article deals with the performances of tourism accommodation facilities (number of tourists, nights spend by tourists in accommodation facilities, occupancy rate and
Nie wszystkie warunki maja zastosowanie do każdego z regionów, ponieważ ich warunki lub zasoby różnią się. Chociaż turystyka może oferować ekonomiczne możliwości rozwoju regionalnego $\mathrm{w}$ oparciu o zasoby terytorialne, jednocześnie wpływ turystyki na wykorzystanie tych zasobów i organizację systemów gospodarczych może negatywnie przyczynić się do zmian i zrównoważonego rozwoju regionu.

\section{Cel, materiał i metodologia}

Celem tego artykułu jest zbadanie wpływu turystyki jako czynnika rozwoju regionu Słowacji wschodniej. Do analizy znaczenia turystyki w regionie wschodniej Słowacji wykorzystywane są wybrane wskaźniki rozwoju turystyki. W artykule omówiono wyniki turystycznych obiektów noclegowych (liczba turystów, noce spędzane przez turystów w obiektach noclegowych, obłożenie i dochody), za- 
revenues), tourism employment and incomes from accommodation taxes. The data from the Statistical Office of the Slovak Republic (SUSR) and selected municipalities are analysed. The object of this article is the region of Eastern Slovakia (ESR), which is one of the four NUTS II regions in Slovakia. The data are analysed for the period 2011 - 2015 and processed using the methods of descriptive statistics (index, variance function).

\section{Research results}

The region of Eastern Slovakia has an area of 15,729 square kilometres and a population of 1.579 million (Figure 1). From NUTS 2 region is the least developed Slovak region in terms of regional income, employment and wage levels. It also accounts for poor research and development infrastructure, lower intensity of innovation activities and low research intensity. In the region of Eastern Slovakia there are 1 105 municipalities including 40 cities.(ec.europa.eu). trudnienie $\mathrm{w}$ turystyce i dochody z podatków od zakwaterowania. Analizowane są dane z Urzędu Statystycznego Republiki Słowackiej (SUSR) i wybranych gmin. Przedmiotem tego artykułu jest region Słowacji wschodniej, który jest jednym z czterech regionów NUTS II na Słowacji. Dane sa analizowane dla lat 2011 - 2015 i przetwarzane przy użyciu metod statystyki opisowej (indeks, funkcja wariancji).

\section{Wyniki badania}

Region Słowacji wschodniej ma powierzchnię 15 729 kilometrów kwadratowych i 1,579 milionów mieszkańców (Rys. 1). Według NUTS 2 region ten jest najsłabiej rozwiniętym regionem słowackim pod względem dochodów regionalnych, poziomu zatrudnienia i płac. Ma on również słabą infrastrukturę badawczo-rozwojową, mniejszą intensywność działań innowacyjnych i małą intensywność badań. W regionie wschodniej Słowacji znajduje się 1105 gmin, w tym 40 miast (ec.europa.eu).

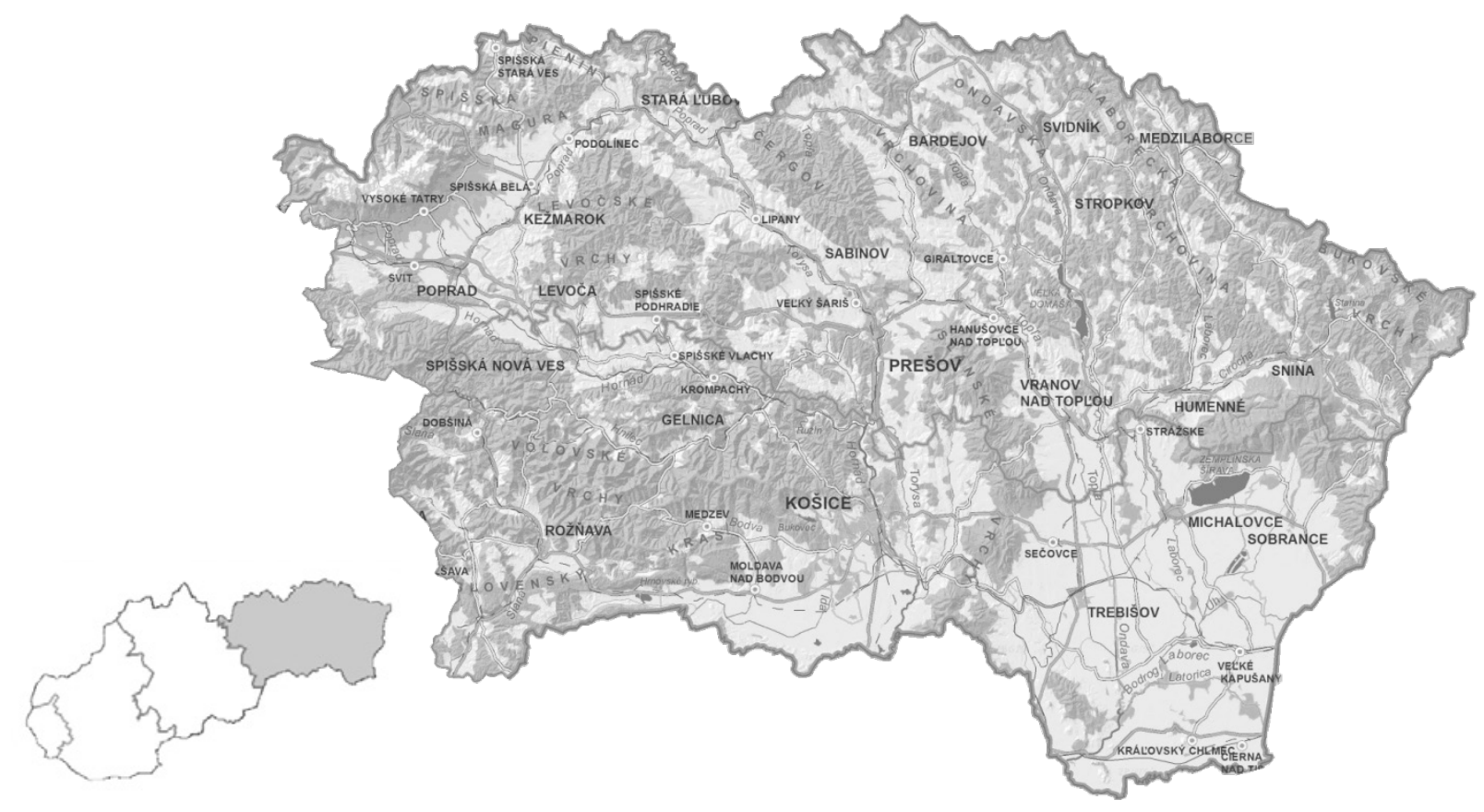

Figure 1. The region of Eastern Slovakia

Rysunek 1. Region Słowacji wschodniej

Source: ec.europa.eu, 2017.

Źródło: ec.europa.eu, 2017.

The tourism in this area has great importance, which could become one of the key sectors in the regional development and employment. There are 6 of 9 Slovak national parks in the territory of Košice and Prešov regions, more than 300 preserved areas and nature attractions, and 107 habitats of the European importance, such as the only cold-water geyser in Europe in Herlany and the deepest canyon of Slovakia (almost $400 \mathrm{~m}$ ) in Zádiel. The most prominent tourist attractions in the Eastern Slovakia include
Turystyka w tym obszarze ma wielkie znaczenie, które może stać się jednym z kluczowych sektorów regionalnego rozwoju i zatrudnienia. Na terenie regionu Koszyc i Preszowa znajduje się 6 z 9 słowackich parków narodowych, ponad 300 obszarów chronionych i atrakcji przyrodniczych oraz 107 siedlisk o znaczeniu europejskim, takich jak jedyny gejzer zimnej wody w Europie znajdujący się w Herlanach i najgłębszy kanion Słowacji w Zádiel (prawie 400 m). Do najbardziej znanych atrakcji turystycznych we wschodniej Słowa- 
the monuments on the UNESCO World Cultural and Natural List as Spiš Castle and surrounding, historical centre of town Bardejov, 6 from 8 listed old wooden churches of Slovakia and the historical centre of town Levoča. Natural heritage includesthe Slovak Karst Cave system enlarged by Ochtínska Aragonit Cave, Dobšinská Ice Cave and Stratenská Cave together with Aggtelek caves in Hungary and Primeval Beech Forests of the Carpathians.

\section{Performances of accommodation facilities}

Identifying the role of tourism demand is essential for evaluating tourism importance in regional development (Bohlin, Brandt, Elbe, 2016). The contribution of tourism in regional development can be evaluated by performances of accommodation facilities (Table 2). cji należą zabytki wpisane na Listę Światowego Dziedzictwa Kulturalnego i Naturalnego UNESCO, takie jak Zamek Spiski i jego okolice, historyczne centrum miasta Bardejov, 6 z 8 zabytkowych drewnianych kościołów Słowacji i historyczne centrum miasta Lewocza. Dziedzictwo naturalne obejmuje system Jaskiń Słowackiego Krasu powiększone o Jaskinię Ochtińską Aragonitową, Dobszyńską Jaskinię Lodową i Jaskinię Strateńską wraz z jaskiniami Aggtelek na Węgrzech i Bukami Pradawnymi w Karpatach.

\section{Wyniki obiektów noclegowych}

Identyfikacja roli zapotrzebowania turystycznego jest niezbędna do oceny znaczenia turystyki w rozwoju regionalnym (Bohlin, Brandt, Elbe, 2016). Wkład turystyki w rozwój regionalny można ocenić na podstawie wyników obiektów noclegowych (tabela 2).

Table 2. Tourists in accommodation facilities by region

Tabela 2. Turyści w obiektach zakwaterowania według regionu

\begin{tabular}{|c|c|c|c|c|c|c|}
\hline \multirow[b]{2}{*}{$\begin{array}{l}\text { Region / Year/ } \\
\text { Region / Rok }\end{array}$} & \multicolumn{2}{|c|}{2011} & \multicolumn{2}{|c|}{2015} & \multirow{2}{*}{$\begin{array}{c}\text { Change of } \\
\text { share/ } \\
\text { Zmiana } \\
\text { udziału }\end{array}$} & \multirow[b]{2}{*}{$\begin{array}{c}\text { Index/ Indeks } \\
\%\end{array}$} \\
\hline & $\begin{array}{c}\text { Tourists/ } \\
\text { Turyści }\end{array}$ & $\begin{array}{c}\text { Share/ } \\
\text { Udział } \\
\%\end{array}$ & $\begin{array}{c}\text { Tourists/ } \\
\text { Turyści }\end{array}$ & $\begin{array}{c}\text { Share/ } \\
\text { Udział } \\
\%\end{array}$ & & \\
\hline $\begin{array}{l}\text { Bratislava region/ } \\
\text { Region Bratysławy }\end{array}$ & 879,878 & 24.64 & $1,194,479$ & 27,58 & 2.95 & 35.76 \\
\hline $\begin{array}{l}\text { Western Slovakia/ } \\
\text { Słowacja zachodnia }\end{array}$ & 699,287 & 19.58 & 833,635 & 19.25 & -0.33 & 19.21 \\
\hline $\begin{array}{c}\text { Central Slovakia/ } \\
\text { Słowacja centralna }\end{array}$ & $1,084,023$ & 30.36 & $1,295,076$ & 29.91 & -0.45 & 19.47 \\
\hline $\begin{array}{c}\text { Eastern Slovakia/ } \\
\text { Słowacja wschodnia }\end{array}$ & 907,905 & 25.42 & $1,007,059$ & 23.26 & -2.17 & 10.92 \\
\hline $\begin{array}{c}\text { Slovakia/ } \\
\text { Słowacja } \\
\end{array}$ & $3,571,093$ & 100.00 & $4,330,249$ & 100.00 & 0.00 & 21.26 \\
\hline $\begin{array}{c}\text { Variation (regions)/ } \\
\text { Zmienność (regionów) }\end{array}$ & - & 19.45 & - & 22.28 & - & - \\
\hline
\end{tabular}

Source: The Statistical Office of the Slovak Republic, 2016.

Źródło: Urząd Statystyczny Republiki Słowackiej, 2016 r.

In 2015, attendance of accommodation facilities increased in all regions. More than a quarter of the tourists were accommodated in the region of Central Slovakia $(29.91 \%)$ and their overall number has risen by $19.47 \%$. The proportion of the Bratislava region increased, but on the other hand, the share of the other three regions decreased. The variation expressed an increase in the gap between the number of tourists in accommodation facilities by regions. This may be caused by several factors. Ineffective or insufficient use of the resources (tourism potential), the improper government policy of tourism development (support of destination management organizations) with a persistently high share of the support focused to Bratislava and the High Tatras (Žilina and Prešov regions). More than $23 \%$ tourists were accommodated in the ESR and their number has risen by $10.92 \%$. Even though the proportion of the ESR in Slovakia has slightly decreased.
W 2015 r. liczba miejsc noclegowych wzrosła we wszystkich regionach. Ponad jedna czwarta turystów została zakwaterowana w regionie Słowacji centralnej $(29,91 \%)$, a ich ogólna liczba wzrosła o $19,47 \%$. Wzrósł udział regionu bratysławskiego, lecz z drugiej strony zmniejszył się udział pozostałych trzech regionów. Różnica wyrażała wzrost rozbieżności między liczbą turystów w obiektach zakwaterowania w poszczególnych regionach. Może to być spowodowane kilkoma czynnikami, takimi jak niedogodne lub niewystarczające wykorzystanie zasobów (potencjał turystyczny), niewłaściwa polityka rządu w zakresie rozwoju turystyki (wsparcie organizacji zarządzających destynacją) z utrzymującym się wysokim udziałem wsparcia ukierunkowanego na Bratysławę i Wysokie Tatry (regiony Żylina i Preszów). Ponad 23\% turystów zostało zakwaterowanych w regionie Słowacji wschodniej (ESR), a ich liczba wzrosła o 10,92\%, pomimo tego, że udział regionu Słowacji wschodniej na Słowacji nieznacznie spadł. W 2015 r. ponad 70\% 
In 2015 , more than $70 \%$ of tourists were registered in Prešov region and the number of tourists in Košice region even decreased by $8 \%$ (table 3 ).

The growth of the number of tourists in the ESR was supported mainly by domestic $(16 \%)$ tourists (Table 4). turystów było zarejestrowanych w regionie Preszowa, a liczba turystów w Koszycach zmniejszyła się nawet o 8\% (tabela 3).

$\mathrm{Na}$ wzrost liczby turystów w regionach Słowacji Wschodniej wpłynęli przede wszystkim turyści krajowi (16\%) (Tabela 4).

Table 3. Tourists in accommodation facilities in the regions of Eastern Slovakia

Tabela 3. Turyści w obiektach noclegowych w regionach Słowacji wschodniej

\begin{tabular}{|c|c|c|c|c|c|c|}
\hline \multirow{2}{*}{$\begin{array}{c}\text { Region / Year/ } \\
\text { Region / Rok }\end{array}$} & \multicolumn{2}{|c|}{2011} & \multicolumn{2}{|c|}{2015} & \multirow{2}{*}{\begin{tabular}{|c|}
$\begin{array}{c}\text { Change of } \\
\text { share/ } \\
\text { Zmiana udziału }\end{array}$ \\
\end{tabular}} & \multirow[b]{2}{*}{$\begin{array}{l}\text { Index \%/ } \\
\text { Indeks \% }\end{array}$} \\
\hline & $\begin{array}{l}\text { Tourists/ } \\
\text { Turyści }\end{array}$ & $\begin{array}{l}\text { Share \%/ } \\
\text { Udział \% }\end{array}$ & $\begin{array}{l}\text { Tourists/ } \\
\text { Turyści }\end{array}$ & $\begin{array}{l}\text { Share \%/ } \\
\text { Udział \% }\end{array}$ & & \\
\hline $\begin{array}{c}\text { Prešov region/ } \\
\text { Region Preszowa }\end{array}$ & 618,470 & 68.12 & 740,701 & 73.55 & 5.43 & 68,12 \\
\hline $\begin{array}{l}\text { Košice region/ } \\
\text { Region Koszyce }\end{array}$ & 289,435 & 31.88 & 266,358 & 26.45 & -5.43 & -7.97 \\
\hline $\begin{array}{c}\text { Eastern Slovakia/ } \\
\text { Słowacja Wschodnia }\end{array}$ & 907,905 & 100.00 & $1,007,059$ & 100.00 & 0.00 & 10.92 \\
\hline
\end{tabular}

Source: The Statistical Office of the Slovak Republic, 2016.

Źródło: Urząd Statystyczny Republiki Słowackiej, 2016.

Table 4. Performances of accommodation facilities in the region of Eastern Slovakia

Tabela 4. Wyniki obiektów noclegowych w regionie Słowacji Wschodniej

\begin{tabular}{|c|c|c|c|c|c|c|c|c|c|}
\hline Indicator/ Year/ Wskaźnik Rok & \multicolumn{3}{|c|}{2011} & \multicolumn{3}{|c|}{2015} & \multicolumn{3}{|c|}{ Index/Indeks \% } \\
\hline \multicolumn{10}{|c|}{ Tourists in accommodation facilities/Turyści w obiektach noclegowych } \\
\hline Eastern Slovakia/Słowacja wschodnia & \multicolumn{3}{|c|}{907,905} & \multicolumn{3}{|c|}{$1,007,059$} & \multicolumn{3}{|c|}{10.92} \\
\hline Slovakia/Słowacja & \multicolumn{3}{|c|}{$3,392,361$} & \multicolumn{3}{|c|}{$4,330,249$} & \multicolumn{3}{|c|}{21.26} \\
\hline Share in Slovakia \%/Udział w Słowacji \% & \multicolumn{3}{|c|}{25.42} & \multicolumn{3}{|c|}{23.26} & \multicolumn{3}{|c|}{$\mathrm{x}$} \\
\hline \multicolumn{10}{|c|}{$\begin{array}{l}\text { Foreign tourists in accommodation facilities/ } \\
\text { Turyści zagraniczni w obiektach noclegowych }\end{array}$} \\
\hline Eastern Slovakia/Słowacja wschodnia & \multicolumn{3}{|c|}{312,971} & \multicolumn{3}{|c|}{317,926} & \multicolumn{3}{|c|}{1.58} \\
\hline Slovakia/Słowacja & \multicolumn{3}{|c|}{$1,460,361$} & \multicolumn{3}{|c|}{$1,721,193$} & \multicolumn{3}{|c|}{29.74} \\
\hline Share in Slovakia \%/Udział w Słowacji \% & \multicolumn{3}{|c|}{21.43} & \multicolumn{3}{|c|}{18.47} & \multicolumn{3}{|c|}{$\mathrm{x}$} \\
\hline \multicolumn{10}{|c|}{ Nights spent by tourists/Noclegi odbyte przez turystów } \\
\hline Eastern Slovakia/Słowacja wschodnia & \multicolumn{3}{|c|}{$2,647,985$} & \multicolumn{3}{|c|}{$2,960,145$} & \multicolumn{3}{|c|}{11.79} \\
\hline Share in Slovakia \%/Udział w Słowacji \% & \multicolumn{3}{|c|}{25.54} & \multicolumn{3}{|c|}{23.97} & & $\mathrm{x}$ & \\
\hline $\begin{array}{l}\text { Nights spent by foreign tourists/ } \\
\text { Noclegi odbyte przez turystów zagranicznych }\end{array}$ & & 904,15 & & & 942,38 & & & 4.23 & \\
\hline Share in Slovakia \%/Udział w Słowacji \% & & 23.75 & & & 21.15 & & & $\mathrm{x}$ & \\
\hline $\begin{array}{c}\text { Structure of nights spent by tour. \%/ } \\
\text { Struktura noclegów odbytych przez wycieczki. \% }\end{array}$ & la & & $\mathrm{F}$ & & 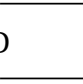 & $\mathrm{F}$ & Chat & ge/Zn & ana \\
\hline Eastern Slovakia/Słowacja wschodnia & 65 & 85 & 34.15 & 68 & 16 & 31.84 & & 2,31 & \\
\hline Slovakia/Słowacja & & 28 & 36.72 & & 92 & 36.08 & & 0,63 & \\
\hline Ayoraco lonoth of ctov/Środnia dtuaoćć nobutu & & 2011 & & & 2015 & & Chat & ge/Zn & ana \\
\hline Average length or stay/sreanla arugosc pobytu & $\mathrm{D}$ & $\mathrm{F}$ & $\mathrm{T}$ & $\mathrm{D}$ & $\mathrm{F}$ & $\mathrm{T}$ & $\mathrm{D}$ & $\mathrm{F}$ & $\mathrm{T}$ \\
\hline Eastern Slovakia (nights)/Słowacja wschodnia (noclegi) & 2.9 & 2.9 & 2.9 & 2.9 & 3.0 & 2.9 & 0.0 & 0.1 & 0.0 \\
\hline Slovakia (nights)/Słowacja (noclegi) & 3.1 & 2.6 & 2.9 & 3.0 & 2.6 & 2.9 & -0.1 & 0.0 & 0.0 \\
\hline Occupancy/Obłoż & & & & & & & Chal & ge/Zn & ana \\
\hline $\begin{array}{c}\text { Eastern Slovakia (\%)/ } \\
\text { Słowacja wschodnia (\%) }\end{array}$ & & 19.05 & & & 21.10 & & & 2.05 & \\
\hline Slovakia (\%)/Słowacja (\%) & & 21.70 & & & 26.10 & & & 4.40 & \\
\hline Turnover for accommodation/Obrc & zakw & aterov & ania & & & & Index & /Indel & $(\%)$ \\
\hline Eastern Slovakia (mil. €)/Słowacja wschodnia (mln €) & & 54.65 & & & 67.40 & & & 23.32 & \\
\hline Slovakia (mil. €)/Słowacja (mln €) & & 254.3 & & & 310.0 & & & 21.87 & \\
\hline Share in Slovakia (\%)/Udział w Słowacji \% & & 21.49 & & & 21.74 & & & - & \\
\hline Average price for accommodation services/Średr & cena 2 & a usłu & i zakwa & erow & ania & & Index & /Indel & $(\%)$ \\
\hline Eastern Slovakia $(€) /$ Słowacja wschodnia $(€)$ & & 22.18 & & & 24.90 & & & 12.26 & \\
\hline Slovakia $(€) /$ Słowacja $(€)$ & & 24.17 & & & 25.10 & & & 3.85 & \\
\hline
\end{tabular}

* D - Domestic tourists, F - Foreign tourists, T - together./ * D - Turyści krajowi, F - Turyści zagraniczni, T - razem.

Source: The Statistical Office of the Slovak Republic, 2016.

Źródło: Urząd Statystyczny Republiki Słowackiej, 2016. 
The number of nights spent by tourists in accommodation facilities increased by $12 \%$. More than $65 \%$ of nights in the region were spent by residents and their share increased by $2.31 \%$. The average occupancy rate of accommodation facilities in the ESR has slightly increased (to 21.10 $\%)$. The positive change showed the revenue from accommodation facilities (increased by $23 \%$ ) which could be also connected with the higher average price for accommodation.

The performances of accommodation facilities in Slovak regions correspond to their level of tourism development and attractiveness. The indicators showed growing importance of tourism in the ESR. However, tourism in Eastern Slovakia region is stimulated mostlyin region of Prešov, particularly in High Tatras.

\section{Tourism's contribution to employment}

In 2015 , tourism directly generated 59,000 jobs in Slovakia $(2.5 \%$ of total employment). The total contribution of tourism to employment (including wider effects of investment, the supply chain and induced income impacts) was 143,000 jobs in 2015 (6.0 $\%$ of total employment) (World Travel and Tourism Council, 2016). The region of Eastern Slovakia has areas with the highest average unemployment rate. Employment in tourism is very specific regarding the seasonality, flexibility, multifunctionality of tourism facilities as well as low salaries. The contribution of tourism to the employment in the ESR is captured in Table 5.
Liczba noclegów odbytych przez turystów w obiektach noclegowych wzrosła o $12 \%$. Ponad 65\% noclegów w regionie zostało udzielonych mieszkańcom, a ich udział wzrósł o 2,31\%. Średni wskaźnik obłożenia obiektów noclegowych w regionie Słowacji wschodniej wzrósł nieznacznie (do 21,10\%). Dodatnia zmiana wykazała przychód $\mathrm{z}$ obiektów noclegowych (wzrost o 23\%), co może być również związane z wyższą średnią ceną zakwaterowania.

Wyniki obiektów noclegowych $w$ regionach słowackich pokrywają się z ich poziomem rozwoju turystyki i atrakcyjności. Wskaźniki wykazały rosnące znaczenie turystyki w regionie Słowacji wschodniej. Pomimo tego, turystyka w regionie Słowacji wschodniej jest stymulowana głównie w regionie preszowskim, szczególnie w Tatrach Wysokich.

\section{Wkład turystyki w zatrudnienie}

W 2015 r. turystyka bezpośrednio wygenerowała 59000 miejsc pracy na Słowacji $2,5 \%$ całkowitego zatrudnienia). Całkowity wkład turystyki w zatrudnienie (w tym szersze skutki inwestycji, łańcuch dostaw i indukowane wpływy dochodowe) wyniósł 143 000 miejsc pracy w 2015 r. (6,0\% całkowitego zatrudnienia) (Światowa Rada Podróży i Turystyki, 2016). Region Słowacji Wschodniej posiada obszary o najwyższej średniej stopie bezrobocia. Zatrudnienie w turystyce jest bardzo specyficzne ze względu na sezonowość, elastyczność, wielofunkcyjność obiektów turystycznych jak również niskie wynagrodzenia. Wkład turystyki w zatrudnienie $\mathrm{w}$ regionie Słowacji wschodniej został przedstawiony w Tabeli 5.

Table 5. Tourism's contribution to employment in the region of Eastern Slovakia

Tabela 5. Wkład turystyki w zatrudnienie w regionie Słowacji wschodniej

\begin{tabular}{|l|c|c|c|}
\hline \multicolumn{1}{|c|}{$\begin{array}{c}\text { Average registered number of employees (persons) /Year/ } \\
\text { Średnia zarejestrowana liczba pracowników (osób) /Rok }\end{array}$} & $\mathbf{2 0 1 1}$ & $\mathbf{2 0 1 5}$ & $\begin{array}{c}\text { Index/ Indeks } \\
\text { (\%) }\end{array}$ \\
\hline $\begin{array}{l}\text { Number of employees in the region of Eastern Slovakia/ } \\
\text { Liczba pracowników w regionie Słowacji wschodniej }\end{array}$ & 358,823 & 327,262 & -8.80 \\
\hline $\begin{array}{l}\text { Accommodation facilities/ } \\
\text { Obiekty noclegowe }\end{array}$ & 3,969 & 2,361 & -40.50 \\
\hline $\begin{array}{l}\text { Restaurant facilities/ } \\
\text { Obiekty gastronomiczne }\end{array}$ & 3,955 & 2,676 & -32.34 \\
\hline $\begin{array}{l}\text { Travel agencies/ } \\
\text { Biura podróży }\end{array}$ & 864 & 358 & -58.51 \\
\hline $\begin{array}{l}\text { Main tourism facilities together (Direct employment)/ } \\
\text { Główne obiekty turystyczne razem (bezpośrednie zatrudnienie) }\end{array}$ & 8,788 & 5,396 & -38.60 \\
\hline $\begin{array}{l}\text { Share in the employment (main tourism facilities) (\%)/ } \\
\text { Udział w zatrudnieniu (główne obiekty turystyczne) (\%) }\end{array}$ & 2.45 & 1.65 & $\mathrm{x}$ \\
\hline $\begin{array}{l}\text { Multifunctional tourism facilities (art, entertainment, recreation, sport facilities)/ } \\
\text { Wielofunkcyjne obiekty turystyczne (sztuka, rozrywka, rekreacja, obiekty sportowe) }\end{array}$ & 5,627 & 4,469 & $-20,58$ \\
\hline $\begin{array}{l}\text { Tourism facilities together/ } \\
\text { Obiekty turystyczne razem }\end{array}$ & 14,415 & 9,865 & $-31,57$ \\
\hline $\begin{array}{l}\text { Share in the employment (tourism facilities together) (\%)/ } \\
\text { Udział w zatrudnieniu (obiekty turystyczne razem) (\%) }\end{array}$ & 4.02 & 3.01 & $\mathrm{x}$ \\
\hline
\end{tabular}

Source: The Statistical Office of the Slovak Republic, 2016.

Źródło: Urząd Statystyczny Republiki Słowackiej, 2016. 
The table contains data on the number of employees for all enterprises and organizations in the region, regardless of the number of employees and the major activity (SUSR, 2016). The data does not include selfemployed persons. Despite that, the statistical data cannot express the accurate tourism employment. In 2015, main tourism facilities (accommodation, restaurant and travel agencies) employed 5,400 employees in the ESR. In comparison with 2010, the employment in main tourism facilities decreased by more $35 \%$. Together with multifunctional tourism facilities (represented by art, entertainment, recreation and sportfacilities) tourism generated in 2015 more than 9,860 jobs.

\section{Incomes from accommodation tax}

The influence of tourism on the development of the ESR can be evaluated with the proportion of accommodation tax. We focused on 24 towns by size (population) and availability of data on the tax for accommodation in 2015. Due to unavailability of data, the remaining municipalities were not included (Table 6).
Tabela zawiera dane dotyczące liczby pracowników we wszystkich przedsiębiorstwach i organizacjach w regionie, niezależnie od liczby pracowników i głównej działalności (SUSR, 2016). Dane nie obejmują osób pracujących na własny rachunek. Pomimo tego, dane statystyczne nie są w stanie określić dokładnego poziomu zatrudnienia w turystyce. W 2015 r. główne obiekty turystyczne (zakwaterowanie, restauracje i biura podróży) zatrudniały 5400 pracowników w regionie Słowacji wschodniej. W porównaniu z 2010 r. zatrudnienie w głównych obiektach turystycznych zmniejszyło się o ponad 35\%. Wraz $\mathrm{z}$ wielofunkcyjnymi obiektami turystycznymi (reprezentowanymi przez sztukę, rozrywkę, rekreację i obiekty sportowe) turystyka wytworzyła w $2015 \mathrm{r}$. ponad 9860 miejsc pracy.

\section{Dochody z podatku od zakwaterowania}

Wpływ turystyki na rozwój regionu Słowacji wschodniej można ocenić za pomoca proporcji podatku od zakwaterowania. Skupiliśmy się na 24 miastach wybranych według wielkości (ludności) i dostępności danych o podatku od zakwaterowania w 2015 roku. Z powodu niedostępności danych pozostałe gminy nie zostały uwzględnione (Tabela 6).

Table 6. Incomes from accommodation taxes in selected municipalities in 2015

Tabela 6. Dochody z podatków od zakwaterowania w wybranych gminach w $2015 \mathrm{r}$.

\begin{tabular}{|c|c|c|c|c|c|}
\hline $\begin{array}{c}\text { Municipality / } \\
\text { Tax/ } \\
\text { Gmina /Podatek }\end{array}$ & $\begin{array}{c}\text { Total tax revenue } \\
\text { (mil. } € \text { )/ } \\
\text { Łączne wpływy z } \\
\text { podatków (mln } € \text { ) }\end{array}$ & $\begin{array}{c}\text { Accommodation } \\
\text { tax (€)d za- } \\
\text { Podatek od za- } \\
\text { kwaterowania (€) }\end{array}$ & $\begin{array}{l}\text { Share }(\%) / \\
\text { Udział (\%) }\end{array}$ & $\begin{array}{c}\text { Planned tax }(€) / \\
\text { Planowany poda- } \\
\text { tek }(€)\end{array}$ & $\begin{array}{c}\text { Percentage of } \\
\text { planned tax (\%) } \\
\text { Procent planbwa } \\
\text { nego podatku (\%) }\end{array}$ \\
\hline Košice & 101.02 & $523,694.00$ & 0.52 & $450,000.00$ & 116.38 \\
\hline Michalovce & 13.93 & $24,244.00$ & 0.17 & $19,000.00$ & 127.60 \\
\hline Spišská Nova Ves & 13.61 & $17,319.20$ & 0.13 & $14,725.00$ & 117.62 \\
\hline Trebišov & 7.58 & $3,000.00$ & 0.04 & $4,270.00$ & 70.26 \\
\hline Rožňava & 6.94 & $14,492.00$ & 0.21 & $21,000.00$ & 69.01 \\
\hline $\begin{array}{c}\text { Moldava nad } \\
\text { Bodvou }\end{array}$ & 3.61 & $11,164.60$ & 0.31 & $9,150.00$ & 122.02 \\
\hline Vel'ké Kapušany & 3.00 & $2,816.23$ & 0.09 & $2,000.00$ & 140.81 \\
\hline Krompachy & 2.82 & $8,877.00$ & 0.31 & $2,000.00$ & 443.85 \\
\hline Sečovce & 2.75 & 357.06 & 0.01 & 468.00 & 76.29 \\
\hline Gelnica & 1.85 & 221.00 & 0.01 & 222.00 & 99.55 \\
\hline Dobšiná & 1.66 & $1,914.50$ & 0.12 & 900.00 & 212.72 \\
\hline Prešov & 35.68 & $30,475.00$ & 0.09 & $24,000.00$ & 126.98 \\
\hline Poprad & 20.32 & $141,266.17$ & 0.70 & $120,000.00$ & 117.72 \\
\hline Humenné & 11.26 & $14,703.00$ & 0.13 & $7,000.00$ & 210.04 \\
\hline Bardejov & 12.46 & $161,799.00$ & 1.44 & $145,000.00$ & 111.59 \\
\hline Vranov nad Topl'ou & 7.74 & $5,600.00$ & 0.07 & - & - \\
\hline Snina & 5.62 & $6,218.80$ & 0.11 & $4,000.00$ & 155.47 \\
\hline Kežmarok & 6.41 & $12,987.20$ & 0.20 & $8,000.00$ & 162.34 \\
\hline Stará L'ubovňa & 5.52 & $1,869.00$ & 0.03 & $1,500.00$ & 124.60 \\
\hline Levoča & 5.81 & $13,052.00$ & 0.22 & $11,500.00$ & 113.50 \\
\hline Sabinov & 4.36 & $2,849.10$ & 0.07 & $2,849.10$ & 100.00 \\
\hline Svidník & 3.91 & $1,499.00$ & 0.04 & $2,000.00$ & 74.95 \\
\hline Stropkov & 3.60 & 860.00 & 0.03 & $1,500.00$ & 57.33 \\
\hline Vysoké Tatry & 3.20 & $677,069.00$ & 21.16 & $596,500.00$ & 113.51 \\
\hline
\end{tabular}

Source: Processed based on the statistical evidence of selected municipalities, 2017.

Źródło: Opracowano na podstawie danych statystycznych wybranych gmin, 2017. 
Except the town of Vysoké Tatry, the revenues from accommodation taxes contributed the minimum part of the total tax revenues in selected municipalities in the ESR. The town of Vysoké Tatry includes all the major tourism resorts in the High Tatras and after the country's capital, it is the most attractive tourist destination in Slovakia. The town of Košice has the second highest revenue from accommodation tax in ESR. This town is economic, cultural and historical centre of ESR. Revenues may be also connected with the highest tax rate for accommodation (1.5 EUR).

Planned tax expressed intentional revenues from accommodation tax to municipalities' budgets in 2015. This reflects the perception of tourism by municipalities in ESR as a factor of development.

\section{Conclusion}

The aim of this article was to examine the influence of tourism as a factor of development of the Eastern Slovakia region. To identify tourism importance, the selected indicators of tourism development were used. We focused on performances of accommodation facilities, tourism's contribution to employment and incomes from accommodation tax.

We can say that tourism in the ESR region in 2015 recorded 1,007,059 tourists accommodated in various facilities, which is an increase of $11 \%$. More than $73 \%$ of the tourists were accommodated in the region of Prešov. In comparison with the growth of the number of tourists in other regions of Slovakia, the growth in this region was slower.

The unemployment rate is one of the most common indicators of regional development. The number of employees in main and multifunctional tourism facilities in the ESRdecreased almost by $31 \%$. The share of employment in main tourism facilities on the total employment was $1.65 \%$, together with the multifunctional tourism facilities it was $3.0 \%$.

The tax for accommodation is a local tax, which is determined by each municipality. The revenues from this tax depends on the number of nights spent by tourists, tax rates for accommodation, the population in municipality, etc. Except the town of Vysoké Tatry and Košice, the revenues from accommodation taxes contributed the minimum part of the total tax revenues in selected municipalities in the ESR.

Based on the analysis of economic impacts of tourism on the development of the ESR we can conclude that tourism has minimal effects on this region. The selected indicators of tourism development in the region cannot themselves identify and explain the overall impact on regional development. However, they can indicate the development of tourism in the region and the basic problems of its development. The development of tourism in this region should be based on better utilization of its natural and historical potential, economic activities connected with tourism as well as the support of socio-
Z wyjątkiem miasta Wysokie Tatry, przychody z podatków od zakwaterowania stanowiły minimalną część całkowitych dochodów podatkowych w wybranych gminach w regionie Słowacji wschodniej. Miasto Wysokie Tatry obejmuje wszystkie najważniejsze ośrodki turystyczne w Tatrach Wysokich, a po stolicy kraju jest najatrakcyjniejszym celem turystycznym na Słowacji. Miasto Koszyce zajmuje drugie miejsce pod względem wielkości dochodów z podatku od zakwaterowania w regionie Słowacji wschodniej. Jest ono gospodarczym, kulturalnym i historycznym centrum regionu Słowacji wschodniej. Przychody mogą również mieć związek z najwyższą stawką podatku za zakwaterowanie (1,5 EUR).

Planowany podatek wyrażał zamierzone wpływy z podatku od zakwaterowania do budżetów gmin w 2015 r. Odzwierciedla to postrzeganie turystyki przez gminy $w$ regionie Słowacji Wschodniej jako czynnik rozwoju.

\section{Podsumowanie}

Celem tego artykułu było zbadanie wpływu turystyki jako czynnika rozwoju regionu Słowacji wschodniej. Aby określić znaczenie turystyki, wykorzystano wybrane wskaźniki rozwoju turystyki. Skoncentrowaliśmy się na wynikach obiektów noclegowych, wpływie turystyki na zatrudnienie i wpływach z podatku od zakwaterowania.

Można powiedzieć, że w regionie Słowacji wschodniej w 2015 roku zarejestrowano 1007059 turystów zakwaterowanych w różnych obiektach, co stanowi wzrost o $11 \%$. Ponad $73 \%$ turystów zostało zakwaterowanych $\mathrm{w}$ regionie Preszowa. W porównaniu ze wzrostem liczby turystów w innych regionach Słowacji, wzrost w tym regionie był wolniejszy.

Stopa bezrobocia jest jednym z najbardziej powszechnych wskaźników rozwoju regionalnego. Liczba pracowników w głównych i wielofunkcyjnych obiektach turystycznych w regionie Słowacji wschodniej spadła o prawie 31\%. Udział zatrudnienia w głównych obiektach turystycznych w zatrudnieniu całkowitym wyniósł $1,65 \%$, a razem $\mathrm{z}$ wielofunkcyjnymi obiektami turystycznymi stanowił on już 3,0\%.

Podatek od zakwaterowania jest podatkiem lokalnym, który ustalany jest osobno przez każdą z gmin. Przychody z tego podatku zależą od liczby noclegów udzielonych turystom, stawek podatkowych za zakwaterowanie, liczebności mieszkańców gminy itp. Z wyjątkiem miast Wysokie Tatry i Koszyce, przychody z podatków od zakwaterowania stanowiły minimalną część całkowitych dochodów podatkowych $\mathrm{w}$ wybranych gminach $\mathrm{w}$ regionie Słowacji wschodniej.

Na podstawie analizy gospodarczych wpływów turystyki na rozwój regionu Słowacji wschodniej można wnioskować, że turystyka ma minimalny wpływ na ten region. Wybrane wskaźniki rozwoju turystyki w regionie nie mogą same w sobie określać i wyjaśniać ogólnego wpływu na rozwój regionalny. Mogą jednak wskazywać na rozwój turystyki w regionie i podstawowe problemy związane $\mathrm{z}$ jego rozwojem. Rozwój turystyki w tym regionie powinien 
economic cohesion and competitiveness of the region on international tourism market by respecting the principles of sustainable development.

\section{Acknowledgements}

The research has been completed within the research project VEGA: 1/0509/16 Perspectives of the Development of Voluntary Tourism in Slovakia. opierać się na lepszym wykorzystaniu jego potencjału z uwagi na uwarunkowanie środowiskowe i historyczne, zakładaniu działalności gospodarczych związanych z turystyką, a także wspieraniu spójności społeczno-gospodarczej i konkurencyjności regionu na międzynarodowym rynku turystycznym poprzez przestrzeganie zasad zrównoważonego rozwoju.

\section{Podziękowania}

Badania zostały zakończone $\mathrm{w}$ ramach projektu badawczego VEGA: 1/0509/16 Perspektywy Rozwoju Turystyki Dobrowolnej na Słowacji.

\section{References/Literatura:}

1. Andraz J. M., Norte N. M., Goncalves H. S. (2015), Effects of tourism on regional asymmetries: Empirical evidence for Portugal. Tourism Management, vol. 50, pp. 257 - 267.

2. Bohlin M., Brandt D., Elbe J. (2016), Tourism as a vehicle for regional development in peripheral areas - myth or reality? A longitudinal case study of Swedish regions. European Planning Studies, vol. 24, pp. 1 - 18.

3. Dwyer L. et al. (2004), Evaluating tourism's economic effects: new and old approaches. Tourism Management, vol 25 (3), pp. $307-317$.

4. Dziuba R. (2016), Sustainable Development of Tourism - EU Ecolabel Standards Illustrated Using the Example of Poland. Comparative Economic Research, vol. 19 (2), pp. $111-126$.

5. Eurostat. http://ec.europa.eu/eurostat, (accessed: 27.02.2017).

6. Gúčik M. et al. (2012), Manažment ciel’ového miesta cestovného ruchu. Dali - BB, Banská Bystrica.

7. Hlavňová B., Pavol M., Sabo S. (2014), Support of development of regional tourism in Slovakia. International Multidisciplinary Scientific GeoConference Surveying Geology and Mining Ecology Management, vol. 2 (5), pp. 649-656.

8. Klamár R. (2016), Development tendencies of regional disparities in the Slovak Republic. Geographica Pannonica, vol. 20 (3), pp. $127-135$.

9. Li H. et al. (2016), Tourism and regional income inequality: Evidence from China. Annals of Tourism Research, vol. 58, pp. 81 $-99$.

10. Ministry of Transport and Construction of the Slovak Republic. (2005), Tourism Regionalisation in Slovak Republic.

11. Ministry of Transport and Construction of the Slovak Republic. (2013), The Strategy of Development of Tourism until 2020.

12. Pedrana M. (2013), Local economic development policies and tourism. An Approach to sustainability and culture. Regional Science Inquiry Journal, vol. 5 (1), pp. 91 - 99.

13. Petrevska B., Manasieva-Gerasimova V. (2012), Tourism in Regional Development: Empirical Evidence. Innovative Issues and Approaches in Social Sciences, vol. 5 (2), pp. 6 - 20.

14. Statistical Office of the Slovak Republic. (2016), https://slovak.statistics.sk (accessed: 27.02.2017).

15. Výrostová E. (2010), Regionálna ekonomika a rozvoj. Iura Edition, Bratislava.

16. World Travel and Tourism Council. (2016), Travel and Tourism Economics Impacts Slovakia 2016. https://www.wttc.org// media/files/reports/economic-impact-research/countries-2016 /slovakia 2016.ashx (accessed: 27.02.2017). 